\title{
Prevalence of allergic diseases and their symptoms in schoolchildren according to the birth mode
}

\author{
Carlos Meza-López ${ }^{1}$, Martín Bedolla-Barajas ${ }^{2 \star}$, Jaime Morales-Romero³, Claudia E. Jiménez-Carrillo4, \\ Tonatiuh R. Bedolla-Pulido ${ }^{1}$, and Edna A. Santos-Valencia ${ }^{5}$ \\ ${ }^{1}$ Servicio de Pediatría, Nuevo Hospital Civil de Guadalajara Dr. Juan I. Menchaca, Guadalajara, Jalisco; ${ }^{2}$ Servicio de Alergia e Inmunología Clínica, \\ Nuevo Hospital Civil de Guadalajara Dr. Juan I. Menchaca, Guadalajara, Jalisco; ${ }^{3}$ Instituto de Salud Pública, Universidad Veracruzana, Xalapa- \\ Enríquez, Veracruz; ${ }^{4}$ Hospital Regional Dr. Valentín Gómez Farías, Instituto de Seguridad Social de los Trabajadores del Estado, Zapopan, Jalisco; \\ ${ }^{5}$ Colegio Mexicano de Inmunología Clínica y Alergia, Puebla, Puebla. México
}

\begin{abstract}
Background: The relationship between birth by cesarean section (CS) and allergic diseases' prevalence continues to be controversial. We aimed to investigate if being born by CS is associated with the prevalence of allergic diseases and their symptoms in schoolchildren. Methods: This study included children between 6 and 7 years of age, selected by population-based sampling. We investigated the presence of allergic diseases and their symptoms, family history of asthma, smoking in parents, breastfeeding, exposure to pets, the season of birth, number of siblings, consumption of unpasteurized cow's milk, and mode of birth. Results: We included 1003 subjects (526 girls), of which $44.2 \%$ were born through CS. The prevalence of allergic diseases did not differ according to birth mode. Asthma in either parent, current smoking by the mother, breastfeeding, and unpasteurized cow's milk consumption were associated with wheezing at some time in life. Conclusions: No association between CS birth mode and allergic diseases and their symptoms was found.
\end{abstract}

Key words: Asthma. Allergic rhinitis. Atopic dermatitis. Cesarean section. Prevalence.

\section{Prevalencia de enfermedades alérgicas y síntomas en escolares de acuerdo con la vía de nacimiento}

\section{Resumen}

Introducción: La relación entre el nacimiento por operación cesárea y las enfermedades alérgicas es controversial. El objetivo del presente estudio fue investigar si el nacimiento por cesárea se asocia con la prevalencia de las enfermedades alérgicas y sus síntomas en escolares. Métodos: Estudio transversal que incluyó una muestra probabilística de niños de 6 a 7 años. Se registraron la presencia de enfermedades alérgicas y sus síntomas, la historia familiar de asma, el tabaquismo en los padres, la alimentación al seno materno, la exposición a mascotas, la estación de nacimiento, el número de hermanos, el consumo de leche no pasteurizada de vaca y la vía de nacimiento. Resultados: Se incluyeron 1003 sujetos (526 niñas), de los cuales el $44.2 \%$ nacieron por cesárea. La prevalencia de enfermedades alérgicas no difirió según la vía de nacimiento. El antecedente de asma en alguno de los progenitores, el tabaquismo actual en la madre, la lactancia materna y el consumo de leche no pasteurizada de vaca se asociaron con sibilancias presentes alguna vez en la vida. Conclusiones: No se demostró asociación entre el nacimiento por cesárea y las enfermedades alérgicas y sus síntomas.

Palabras clave: Asma. Rinitis alérgica. Dermatitis atópica. Operación cesárea. Prevalencia.

$\begin{array}{llr}\text { Correspondence: } & \text { Date of reception: 30-04-2020 } & \text { Available online: 02-03-2021 } \\ \text { *Martín Bedolla-Barajas } & \text { Date of acceptance: 28-07-2020 } & \text { Bol Med Hosp Infant Mex. 2021;78(2):130-135 } \\ \text { E-mail: drmbedbar@gmail.com } & \text { DOI: 10.24875/BMHIM.20000114 } & \text { www.bmhim.com }\end{array}$

1665-1146/@ 2020 Hospital Infantil de México Federico Gómez. Published by Permanyer. This is an open access article under the CC BY-NC-ND license (http://creativecommons.org/licenses/by-nc-nd/4.0/). 


\section{Introduction}

Recently, an international trend has been observed regarding the increase of births by cesarean section (CS). Mexico is among the countries that belong to the Organization for Economic Cooperation and Development with a high proportion of births by this mode ${ }^{1}$. According to national figures, the frequency of CS increased from $30 \%$ in 2000 to $37.4 \%$ in 2006 , and $45.1 \%$ in $2012^{2}$. Birth by CS favors modifications of the intestinal microbiota, which has been related to alterations in cytokine production. Therefore, children born by this route seem to be at greater risk of developing allergic diseases ${ }^{3}$. Since the prevalence of asthma, allergic rhinitis, and atopic dermatitis has increased significantly worldwide (Mexico is no exception ${ }^{4,5}$ ), a possible association between the birth mode and the development of allergic diseases has been raised. However, available studies have shown inconsistent results $^{6-14}$. Since there is little evidence in our country, we hypothesized that the prevalence of allergic diseases and their symptoms are higher in schoolchildren born by $\mathrm{CS}$ than in those born vaginally.

\section{Methods}

\section{Design and sampling}

We conducted a cross-sectional study ${ }^{15}$. According to the Ministry of Education of Jalisco, 3946 children aged 6-7 were enrolled in public and private primary schools in Tepatitlán, Jalisco. With the idea of obtaining a larger sample size to estimate the overall prevalence of asthma, allergic rhinitis, and atopic dermatitis in schoolchildren aged 6-7 years, an expected frequency of $50 \%$ (the highest scenario), a $95 \%$ confidence interval $(\mathrm{Cl})$, and a $3 \%$ error were considered. Therefore, the minimum sample size was 841 subjects, which was increased by almost $20 \%$ through randomized, stratified, and cluster sampling.

\section{Measurements}

The prevalence of allergic diseases and their symptoms was determined using the International Study of Asthma and Allergies in Childhood (ISAAC) questionnaires in the Spanish version, previously adapted for Mexico ${ }^{16}$. The ISAAC study is a worldwide effort that was developed in three phases. Phase I aimed to determine the prevalence of asthma, allergic rhinitis, and atopic dermatitis in two different age groups: one group of children aged 6-7 years, and the other, children aged 13-14 years. Phase II served to identify factors associated with allergic diseases. Finally, phase III allowed the evaluation of a particular trend in the prevalence of allergic diseases ${ }^{17}$. Consequently, our study is framed within phase II.

In addition, we asked participants about the maternal and paternal history of asthma and allergic diseases. We investigated if either of the parents had asthma or any allergies. We also investigated the family history of current tobacco consumption, maternal breastfeeding for at least 4 months, regardless of whether it was exclusive, living with dogs or cats inside the house, the season of the year in which the child was born, consumption of unpasteurized cow's milk, and the number of siblings. The period of fieldwork took place from April 2012 to April 2013.

\section{Analysis}

The prevalence of allergic diseases and their symptoms was determined for each birth mode. The proportions were compared through the $\chi^{2}$ test, while the Student's t-test or Mann-Whitney U test were used for the means or medians, respectively. Associations between allergic diseases and their symptoms and the birth mode were evaluated through odds ratios (OR) and $95 \% \mathrm{Cl}$. Multivariate analyses were used to identify factors associated with the prevalence of wheezing at some point in life. Statistical significance was established with a $p \leq 0.05$. The IBM $^{\circledR}$ SPSS $^{\circledR}$ Statistics 20 program (IBM Corp., Armonk, NY, USA) was used to analyze the data.

\section{Ethics}

The Ethics and Research Committee of the Nuevo Hospital Civil de Guadalajara Dr. Juan I. Menchaca, the Sanitary Jurisdiction Number III Altos Sur of the Ministry of Health of Jalisco, and the Regional Delegation of Educational Services approved this study. The parents or guardians of the participating children signed an informed consent form.

\section{Results}

A total of 1003 school children were included $(52.4 \%$ female). The proportion of CS was $44.2 \%$, and $55.8 \%$ by vaginal route. There was no difference in the birth mode between genders. The paternal asthma history, current smoking history, living with pets inside the 
Table 1. Characteristics of the population studied according to the birth mode

\begin{tabular}{|c|c|c|c|c|c|}
\hline \multirow[t]{3}{*}{ Variables } & \multicolumn{5}{|c|}{ Birth mode } \\
\hline & \multicolumn{2}{|c|}{ Cesarean section ( $n=443$ ) } & \multicolumn{3}{|c|}{ Vaginal $(n=560)$} \\
\hline & n & $\%$ & $\mathbf{n}$ & $\%$ & p-value \\
\hline $\begin{array}{l}\text { Gender } \\
\text { Female } \\
\text { Male }\end{array}$ & $\begin{array}{l}234 \\
209\end{array}$ & $\begin{array}{l}52.8 \\
47.2\end{array}$ & $\begin{array}{l}292 \\
268\end{array}$ & $\begin{array}{l}52.1 \\
47.9\end{array}$ & 0.831 \\
\hline $\begin{array}{l}\text { Family history of allergic disease } \\
\text { Mother with asthma } \\
\text { Father with asthma } \\
\text { Mother with allergy } \\
\text { Father with allergy } \\
\text { Current smoking by the mother } \\
\text { Current smoking by the father } \\
\text { Smoking by a family member } \\
\text { Dog in the house } \\
\text { Cat in the house } \\
\text { Breastfeeding for } 4 \text { months at least } \\
\text { Unpasteurized cow's milk consumption }\end{array}$ & $\begin{array}{c}16 \\
19 \\
72 \\
34 \\
65 \\
143 \\
127 \\
100 \\
34 \\
285 \\
255\end{array}$ & $\begin{array}{c}3.6 \\
4.3 \\
16.3 \\
7.7 \\
14.7 \\
32.3 \\
28.7 \\
22.6 \\
7.7 \\
64.3 \\
57.6\end{array}$ & $\begin{array}{c}37 \\
22 \\
79 \\
46 \\
80 \\
203 \\
194 \\
135 \\
37 \\
390 \\
326\end{array}$ & $\begin{array}{c}6.6 \\
3.6 \\
14.1 \\
8.2 \\
14.3 \\
36.3 \\
34.6 \\
24.1 \\
6.6 \\
69.6 \\
58.2\end{array}$ & $\begin{array}{l}0.035 \\
0.775 \\
0.345 \\
0.754 \\
0.863 \\
0.182 \\
0.044 \\
0.569 \\
0.513 \\
0.075 \\
0.835\end{array}$ \\
\hline $\begin{array}{l}\text { Season of birth } \\
\text { Spring } \\
\text { Summer } \\
\text { Autumn } \\
\text { Winter }\end{array}$ & $\begin{array}{c}93 \\
100 \\
133 \\
109\end{array}$ & $\begin{array}{l}21.4 \\
23.0 \\
30.6 \\
25.1\end{array}$ & $\begin{array}{l}108 \\
140 \\
168 \\
134\end{array}$ & $\begin{array}{l}19.6 \\
25.5 \\
30.6 \\
25.1\end{array}$ & 0.798 \\
\hline $\begin{array}{l}\text { Number of siblings } \\
\text { No siblings } \\
\begin{array}{l}1 \\
>1 \\
\geq 3\end{array}\end{array}$ & $\begin{array}{c}48 \\
157 \\
238 \\
94\end{array}$ & $\begin{array}{l}10.8 \\
35.4 \\
53.7 \\
21.2\end{array}$ & $\begin{array}{c}53 \\
156 \\
351 \\
199\end{array}$ & $\begin{array}{c}9.5 \\
27.9 \\
62.7 \\
35.5\end{array}$ & $\begin{aligned} & 0.015 \\
< & 0.0001\end{aligned}$ \\
\hline
\end{tabular}

house, breastfeeding, unpasteurized cow's milk consumption, and the season of the year, in which the birth occurred are shown in table 1. Children born by vaginal delivery showed a higher frequency of mothers with asthma $(p=0.035)$, a higher proportion of family members with current smoking $(p=0.044)$, and more siblings $(p<0.0001)$.

Table 2 compares the prevalence of allergic diseases among children born by CS or vaginal delivery. In general, no differences were observed between the groups, except wheezing at some time in life, which tended to be more frequent in CS-born children ( $O R=1.33, p=0.054)$.

The prevalence of wheezing at some time in life was higher when either parent had asthma or with current smoking by the mother, while breastfeeding $\geq 4$ months and unpasteurized cow's milk consumption acted as protective factors for wheezing at some time in life (Table 3).

\section{Discussion}

This study found no association between the prevalence of allergic diseases and the symptoms investigated regarding the birth mode. Conversely, we identified other variables as independent factors associated with the prevalence of wheezing at some time in life.

The frequency of allergic diseases has increased in Mexico. For example, in Cuernavaca, the prevalence increased notoriously in just a 7-year period ${ }^{4}$; similar findings were observed in Guadalajara ${ }^{5}$. CS birth has been identified as a contributing factor to this phenomenon, but the results are still contradictory. A meta-analysis showed that CS birth increases the risk of asthma and allergic rhinitis by $18 \%$ and $23 \%$, respectively ${ }^{6}$. Other studies have found similar results for asthma ${ }^{7,8}$. In nearly 70,000 European children, CS birth was found to significantly increase the risk of asthma during school age when the CS was elective and not an emergency ${ }^{9}$; however, of the nine cohorts included in this study, only two found an association between CS birth and asthma.

Furthermore, it is notorious that such an event was not reaffirmed in a cohort that included more than 50,000 children. Another noteworthy point is the wide 
Table 2. Comparison of the prevalence of allergic diseases among children born by cesarean section or vaginal delivery

\begin{tabular}{|c|c|c|c|c|c|c|}
\hline \multirow[t]{3}{*}{ Variables } & \multicolumn{6}{|c|}{ Birth mode } \\
\hline & \multicolumn{2}{|c|}{ Vaginal $(n=560)$} & \multicolumn{2}{|c|}{ Cesarean section ( $n=443$ ) } & \multirow[t]{2}{*}{ OR $(95 \%$ CI $)$} & \multirow[t]{2}{*}{$\mathbf{p}$} \\
\hline & $\mathbf{n}$ & $(\%)$ & $\mathbf{n}$ & $(\%)$ & & \\
\hline Wheezing at some time in life & 120 & 21.4 & 118 & 26.6 & $1.33(0.99-1.78)$ & 0.054 \\
\hline $\begin{array}{l}\text { Symptoms in the previous year } \\
\text { Wheezing } \\
\text { Wheezing with exercise } \\
\text { Night cough } \\
\text { Asthma } \\
\text { Rhinitis at some time } \\
\text { Rhinitis in the previous year } \\
\text { Rhinitis and conjunctivitis in the previous year } \\
\text { Allergic rhinitis } \\
\text { Exanthema at some time } \\
\text { Pruritic exanthema in the previous year } \\
\text { Flexural exanthema } \\
\text { Atopic dermatitis }\end{array}$ & $\begin{array}{c}50 \\
40 \\
182 \\
43 \\
187 \\
150 \\
52 \\
23 \\
49 \\
36 \\
31 \\
11\end{array}$ & $\begin{array}{c}8.9 \\
7.1 \\
32.5 \\
7.7 \\
33.4 \\
26.8 \\
9.3 \\
4.1 \\
8.8 \\
6.4 \\
5.5 \\
2.0\end{array}$ & $\begin{array}{c}46 \\
25 \\
139 \\
37 \\
155 \\
126 \\
47 \\
25 \\
42 \\
29 \\
22 \\
13\end{array}$ & $\begin{array}{c}10.4 \\
5.6 \\
31.4 \\
8.4 \\
35.0 \\
28.4 \\
10.6 \\
5.6 \\
9.5 \\
6.5 \\
4.9 \\
2.9\end{array}$ & $\begin{array}{l}1.18(0.77-1.80) \\
0.78(0.46-1.30) \\
0.95(0.73-1.24) \\
1.09(0.69-1.73) \\
1.07(0.82-1.40) \\
1.09(0.82-1.44) \\
1.16(0.76-1.75) \\
1.39(0.78-2.49) \\
1.09(0.71-1.68) \\
1.02(0.61-1.69) \\
0.89(0.51-1.56) \\
1.51(0.67-3.40)\end{array}$ & $\begin{array}{l}0.437 \\
0.339 \\
0.705 \\
0.696 \\
0.596 \\
0.560 \\
0.485 \\
0.260 \\
0.689 \\
0.940 \\
0.689 \\
0.321\end{array}$ \\
\hline
\end{tabular}

OR: odds ratio; $\mathrm{Cl}$ : confidence interval.

Table 3. Factors associated with wheezing at some time in the life of school children

\begin{tabular}{|c|c|c|c|c|c|c|}
\hline \multirow[t]{2}{*}{ Variables } & \multicolumn{3}{|c|}{ Univariate analysis* } & \multicolumn{3}{|c|}{ Multivariate analysis** } \\
\hline & OR & $95 \%$ Cl & p & OR & $95 \%$ CI & $\mathbf{p}$ \\
\hline Cesarean section birth & 1.33 & $0.99-1.78$ & 0.054 & 1.34 & $0.99-1.80$ & 0.058 \\
\hline Mother with asthma & 1.87 & $1.04-3.34$ & 0.033 & 1.86 & $1.02-3.40$ & 0.044 \\
\hline Father with asthma & 3.60 & $1.92-6.77$ & $<0.0001$ & 3.24 & $1.70-6.18$ & $<0.0001$ \\
\hline Current smoking by the mother & 1.81 & $1.24-2.64$ & 0.002 & 1.74 & $1.18-2.57$ & 0.005 \\
\hline Breastfeeding at least for 4 months & 0.69 & $0.51-0.94$ & 0.016 & 0.71 & $0.52-0.97$ & 0.031 \\
\hline Unpasteurized cow's milk consumption & 0.67 & $0.50-0.90$ & 0.007 & 0.70 & $0.52-0.94$ & 0.017 \\
\hline
\end{tabular}

${ }^{*}$ Odds ratio calculated with a $2 \times 2$ table; ${ }^{*} 0$ dds ratio calculated by a binary logistic regression.

All variables were entered simultaneously in a single block. Selection method; Enter.

OR: odds ratio; $\mathrm{Cl}$ : confidence interval.

variability found in asthma's risk (from $2 \%$ to $46 \%$ ). Moreover, in an elective CS, the risk range variation widens (from $2 \%$ to $75 \%$ ) ) $^{9}$ Recently, a study in Australia analyzed two cohorts of children to assess whether CS birth predicts allergic disease. Only one of these cohorts showed a significant association with asthma ${ }^{18}$. A cross-sectional study analyzed data from more than 180,000 surveys in China. The results indicated that CS birth increased the likelihood of asthma in schoolchildren and adolescents by more than $30 \%{ }^{19}$. Regardless of the study design, it appears that the association between asthma and CS birth will continue to be an issue for analysis.
The association between birth mode and allergic rhinitis or atopic dermatitis has received less attention, and the results have been inconsistent. In the case of atopic dermatitis, a longitudinal study in Greece followed more than 450 children up to the age of 3 years and found that being born by CS is not associated with an increased risk of atopic dermatitis, but with an increased risk of food allergy ${ }^{10}$. In contrast, a study in Korea showed that adolescents who were born by CS were $50 \%$ more likely to suffer from atopic dermatitis ${ }^{11}$. For allergic rhinitis, children born by CS showed a $60 \%$ chance of developing allergic rhinitis by 6 years of age in Brazil ${ }^{12}$. Recently, two studies aimed to identify 
perinatal factors related to allergic rhinitis. One study showed that being born vaginally decreased allergic rhinitis risk, but this was only evident when accompanied by breastfeeding for at least 12 months $^{13}$. In the other study, being born by CS was an independent factor associated with developing allergic rhinitis ${ }^{14}$. Our results are consistent with those studies that found no association between the birth mode and the prevalence of allergic diseases and their symptoms in schoolchildren.

Several mechanisms have been proposed to explain how CS birth increases asthma risk in children. It is known that microbiota has particular relevance because it is modified in CS delivery newborns. For example, a study found that oral bacteria species, Lactobacillus, Prevotella, and Gardnerella, predominated in the vaginal birth group, while Petrimonas, Bacteroides, and Desulfovibrio, among others, predominated in the CS birth group ${ }^{20}$. However, other factors also contribute to modifying the microbiota during the perinatal period, such as antibiotics, no labor in elective CS mothers, breastfeeding characteristics, and mothers with obesity as a determinant for $\mathrm{CS}^{21}$.

In the univariate analysis, we found that the variable wheezing at some time in life showed a tendency to be more frequent in children born by CS than those born vaginally. For that reason, we decided to include this variable in a multivariate analysis. However, we found no evidence of association. Our results differed markedly from the findings in a recent longitudinal study, which showed a 1.83 times greater relative risk of experiencing wheezing in children born by $\mathrm{CS}^{22}$.

Moreover, in the primary analysis, we showed that allergic diseases were not associated with maternal smoking history, breastfeeding, or unpasteurized cow's milk consumption ${ }^{15}$; however, in the new analysis, these factors were related to wheezing at some time in life. During the first years of life, tobacco smoke exposure has been related to wheezing, although this event has not always been considered this way. We observed that smoking by the mother was related to the prevalence of wheezing at some time in life. A Spanish study showed that infants with smoking mothers were at increased risk of wheezing during the first year of life ${ }^{23}$. Recently, a cohort study conducted in nine European countries revealed that children of mothers who smoked after birth were $60 \%$ more likely to develop wheezing at 12-24 months of $\mathrm{age}^{24}$. We asked ourselves why children of mothers who smoked have a higher frequency of wheezing at some time in their lives. From a social perspective in Mexico, women's participation in the labor market is much lower than men's (43\% vs. $77 \%)^{25}$. Indirectly, as this fact forces women to spend more time at home, smoking mothers' children are at greater risk of exposure to tobacco smoke and, therefore, more likely to wheeze.

Breastfeeding is recognized for its multiple benefits, such as reducing the risk of necrotizing enterocolitis, leukemia, and obesity, among other diseases in children. Furthermore, breast milk reduces the incidence of gastrointestinal infections and respiratory infections ${ }^{26}$. The antiviral activity of breast milk ${ }^{27}$ probably contributed to a decrease in the number of viral infections associated with wheezing in children. However, breast milk's protective effect on wheezing has not always been observed; for example, in the EuroPrevall study ${ }^{24}$ and another study in Spain ${ }^{23}$. According to our results, breastfeeding is related to a lower wheezing frequency.

Available evidence shows that unpasteurized cow's milk consumption is associated with a lower prevalence of allergic diseases and respiratory infections. In Europe, raw cow's milk consumption before 1 year of age decreased the risk of asthma, and something similar was observed with wheezing during the first 12 months of life ${ }^{28}$. In another study, raw or boiled cow's milk consumption was inversely related to rhinitis, respiratory infections, otitis, and fever in the first year of life ${ }^{29}$. The arguments for which cow's milk modulates the immune response include a higher concentration of transforming growth factor-beta (TGF $\beta-1$ ) and TGF $\beta 2$ in comparison to human milk, the presence of bovine lactoferrin and interleukin 10, a higher concentration of immunoglobulin $\mathrm{G}$, and a lower concentration of oligosaccharides, among others ${ }^{30}$. Thus, the reduction in respiratory infections promoted by the consumption of unpasteurized cow's milk probably contributed to the lower frequency of wheezing at some time in life observed in our study.

This study's limitations should be considered for the best interpretation of the results since they could not reject the null hypothesis. The first is the lack of verification of the diagnoses of allergic diseases. Second, it is necessary to emphasize the absence of questions to identify the conditions that motivated the decision to terminate a pregnancy through CS. Third, questions aimed at identifying perinatal disorders are missing, as they have been reported to contribute to the development of allergic diseases. Furthermore, we did not delve into the characteristics of breastfeeding, unpasteurized cow's milk consumption, or children's exposure to tobacco smoke.

Conversely, among the analysis strengths, we could mention the sampling technique and the multivariate 
analysis, including other possible predictors of wheezing. As we know, the objective of multivariate analysis is to find groups of variables (models) that explain together the event of interest. In this case, wheezing at some time in life was selected as a dependent variable since it showed a tendency to be associated with the birth mode (CS) in the univariate analysis. However, in multivariate analysis, the birth mode only showed a borderline association with wheezing when analyzed in combination with other variables.

In summary, no significant association was demonstrated between CS birth and the prevalence of asthma, allergic rhinitis, or atopic dermatitis. A relevant finding was a higher prevalence of wheezing at some time in life when either parent indicated a history of asthma or current smoking by the mother but was lower when the duration of breastfeeding was at least 4 months and the children consumed unpasteurized cow's milk.

\section{Ethical disclosures}

Protection of human and animal subjects. The authors declare that no experiments were performed on humans or animals for this study.

Confidentiality of data. The authors declare that they have followed their work center's protocols on patient data publication.

Right to privacy and informed consent. The authors have obtained the written informed consent of the patients or subjects mentioned in the article. The corresponding author has this document.

\section{Conflicts of interest}

The authors declare no conflicts of interest.

\section{Funding}

None.

\section{References}

1. Schnapp SC, Sepúlveda SE, Robert SJ. Operación cesárea. Rev Med Clin Condes. 2014;25:987-92.

2. Encuesta Nacional de Salud y Nutrición. Elevada Recurrencia a las Cesáreas: Revertir la Tendencia y Mejorar la Calidad en el Parto, Evidencia Para la Política Pública en Salud. Morelos: Instituto Nacional de Salud Pública; 2012. Available from: https://ensanut.insp.mx/encuestas/ ensanut2012/doctos/analiticos/Cesareas.pdf.

3. Sphar JE, Krawiec ME. The early origins of asthma: nature, nurture, or parturition? Ann Allergy Asthma Immunol. 2005;94:211-2.

4. Barraza-Villarreal A, Hernández-Cadena L, Moreno-Macías H, Ramírez-Aguilar M, Romieu I. Trends in the prevalence of asthma and other allergic diseases in schoolchildren from Cuernavaca, Mexico. Allergy Asthma Proc. 2007;28:368-74.
5. Morales-Romero J, Bedolla-Barajas M, López-Cota GA, Bedolla-Pulido TI, Bedolla-Pulido TR, Navarro-Lozano E, et al. Tendencia de la prevalencia de asma y sus síntomas en los adolescentes tardíos mexicanos en un periodo de siete años. Rev Alerg Mex. 2018;65:331-40.

6. Bager $P$, Wohlfahrt $J$, Westergaard $T$. Caesarean delivery and risk of atopy and allergic disease: meta-analyses. Clin Exp Allergy. 2008;38:634-42.

7. Thavagnanam S, Fleming J, Bromley A, Shields MD, Cardwell CR. A meta-analysis of the association between Caesarean section and childhood asthma. Clin Exp Allergy. 2008;38:629-33.

8. Huang $L$, Chen $Q$, Zhao $Y$, Wang W, Fang F, Bao Y. Is elective cesarean section associated with a higher risk of asthma? A meta-analysis. J Asthma. 2015;52:16-25.

9. Rusconi F, Zugna D, Annesi-Maesano I, Baïz N, Barros H, Correia S, et al. Mode of delivery and asthma at school age in 9 European birth cohorts. Am J Epidemiol. 2017;185:465-73.

10. Papathoma E, Triga M, Fouzas S, Dimitriou G. Cesarean section delivery and development of food allergy and atopic dermatitis in early childhood. Pediatr Allergy Immunol. 2016;27:419-24.

11. Yu M, Han K, Kim DH, Nam GE. Atopic dermatitis is associated with caesarean sections in Korean adolescents, but asthma is not. Acta Paediatr. 2015;104:1253-8.

12. Vieira BH, Oliveira VG, de Oliveira VT, Augusto CP, de Souza TC, Costa GA, et al. Increased risk of allergic rhinitis among children delivered by cesarean section: a cross-sectional study nested in a birth cohort. BMC Pediatr. 2016;16:57.

13. Han DH, Shin JM, An S, Kim JS, Kim DY, Moon S, et al. Long-term breastfeeding in the prevention of allergic rhinitis: allergic rhinitis cohort study for kids (ARCO-kids study). Clin Exp Otorhinolaryngol. 2019;12:301-7.

14. Li Y, Jiang Y, Li S, Shen X, Liu J, Jiang F. Pre-and postnatal risk factors in relation to allergic rhinitis in school-aged children in China. PLoS One. 2015;10:e0114022.

15. Bedolla-Barajas M, Ramírez-Cervantes F, Morales-Romero J, Pérez-Molina J, Meza-López C, Delgado-Figueroa N. A rural environment does not protect against asthma or other allergic diseases amongst Mexican children. Allergol Immunopathol (Madr). 2018;46:31-8.

16. Tatto-Cano MI, Sanín-Aguirre LH, González V, Ruiz-Velasco S, Romieu I. Prevalencia de asma, rinitis y eczema en escolares de la ciudad de Cuernavaca, México. Salud Publica Mex. 1997;39:497-506.

17. Asher MI, Keil U, Anderson HR, Beasley R, Crane J, Martínez F, et al. International study of asthma and allergies in childhood (ISAAC): rationale and methods. Eur Respir J. 1995;8:483-91.

18. Liao Z, Lamb KE, Burgner D, Ranganathan S, Miller JE, Koplin JJ, et al. No obvious impact of caesarean delivery on childhood allergic outcomes: findings from Australian cohorts. Arch Dis Child. 2020;105:664-70.

19. Yu B, Dai L, Chen J, Sun W, Chen J, Du L, et al. Prenatal and neonatal factors involved in the development of childhood allergic diseases in Guangzhou primary and middle school students. BMC Pediatr. 2019;19:479.

20. Li H, Wang J, Wu L, Luo J, Liang X, Xiao B, et al. The impacts of delivery mode on infant's oral microflora. Sci Rep. 2018;8:11938.

21. Stinson LF, Payne MS, Keelan JA. A critical review of the bacterial baptism hypothesis and the impact of cesarean delivery on the infant microbiome. Front Med (Lausanne). 2018;5:135.

22. Higgins D, Karmaus W, Jiang Y, Banerjee P, Sulaiman IM, Arshad HS. Infant wheezing and prenatal antibiotic exposure and mode of delivery: a prospective birth cohort study. J Asthma. 2020:1-12. doi: 10.1080/027 70903.2020.1734023. Epub ahead of print.

23. Álvarez-Álvarez I, Niu H, Aguinaga-Ontoso I, Guillén-Grima F. Prevalence and risk factors for wheezing in infants in the region of Pamplona, Spain. Allergol Immunopathol (Madr). 2016;44:415-21.

24. Selby A, Munro A, Grimshaw KE, Cornelius V, Keil T, Grabenhenrich L, et al. Prevalence estimates and risk factors for early childhood wheeze across Europe: the EuroPrevall birth cohort. Thorax. 2018;73:1049-61.

25. Moctezuma-Navarro D, Narro-Robles J, Orozco-Hernández L. La mujer en México: inequidad, pobreza y violencia. Rev Mex Cienc Polit Soc. 2014;59:117-46

26. Brahm $P$, Valdés $V$. Beneficios de la lactancia materna y riesgos de no amamantar. Rev Chil Pediatr. 2017;88:7-14.

27. Cordero MJ, García LB, López AM, Barrilao RG, Rodríguez EH, Villar NM. Beneficios inmunológicos de la leche humana para la madre y el niño. Revisión sistemática. Nutr Hosp. 2016;33:482-93.

28. Loss G, Apprich S, Waser M, Kneifel W, Genuneit J, Büchele G, et al The protective effect of farm milk consumption on childhood asthma and atopy: the GABRIELA study. J Allergy Clin Immunol. 2011;128:766-73.

29. Loss G, Depner M, Ulfman LH, van Neerven RJ, Hose AJ, Genuneit J, et al. Consumption of unprocessed cow's milk protects infants from common respiratory infections. J Allergy Clin Immunol. 2015;135: 56-62.

30. Perdijk O, van Splunter M, Savelkoul HF, Brugman S, van Neerven RJ. Cow's milk and immune function in the respiratory tract: potential mechanisms. Front Immunol. 2018;9:143. 